\title{
Mutagenicity of textile dye products
}

\author{
Klaus Schneider ${ }^{1}$, Christoph Hafner ${ }^{2}$, Ismene Jäger ${ }^{2}$ \\ This is a reprint of an article published in \\ Journal of Applied Toxicology 24, 83-91 (2004) （http://www.interscience.wiley.com) \\ ${ }^{1}$ Forschungs- und Beratungsinstitut \\ Gefahrstoffe (FoBiG) GmbH \\ Werderring 16 \\ 2 Hydrotox $\mathrm{GmbH}$ \\ Bötzinger Straße 29 \\ D-79089 Freiburg \\ D-79111 Freiburg \\ phone: $+49-761-3860812$ \\ fax: +49-761-38608-20 \\ mail: klaus.schneider@fobig.de
}

Key words: Textile dyes, mutagenicity testing, mutagenicity evaluation, Ames test, mouse lymphoma assay, existing substances

\section{Abstract}

Within an EU-funded research project, 281 textile dye products in use at 9 textile finishing companies from 8 European countries were assessed for potential mutagenic properties. Most of the dyes belonged to the so-called existing substances. Data sources considered were data published in the literature, unpublished industrial data provided by dye producing companies and laboratory testing. Data on mutagenicity are virtually absent for many of the dyes. Unpublished test results performed on behalf of the dye manufacturing industry proved to be an important data source, which is not accessible under usual circumstances. Four dye stuffs contained in seven dye products in use at the textile finishing companies were judged to be mutagenic based on published data from literature. Mutagenicity testing using Salmonella typhimurium, strains TA98 and TA100, revealed positive results for about $28 \%$ (15 out of 53) of the dye products investigated. Upon further testing with the mouse lymphoma assay ( $\left(\mathrm{L} 5178{\mathrm{Y} / \mathrm{TK}^{+-}}^{+}\right.$) $67 \%$ (6 out of 9) of Ames-positive dyes proved to be mutagenic in this mammalian cell test. All data sources combined led to an overall assessment as being mutagenic for 14 dye products out of 281 . For 16 there is a suspicion of mutagenicity due to positive responses in one test. Still, 71 of the dye products are without any data on mutagenicity. This paper describes the data aggregation process, evaluation criteria, the overall assessment, and exemplifies controversial evaluations.

\section{Introduction}

Possible genotoxic effects of textile dyes are most often discussed with respect to selected azo dyes (Platzek, 1996). Some of these dyes, which contain an azo group (-N=N-), are able to split off genotoxic and carcinogenic amines (e.g. Acid Red 85, which releases benzidine). The use of these dyes has been drastically reduced in Europe due to national regulations 
(e.g. by the German Food and Commodities Act; similar regulations exist in the Netherlands and France) and textile quality labels (EU flower, Oeko-Tex Standard 100), but may still be a problem in non-European countries.

Whereas hazards resulting from these azo dyes, which give rise to carcinogenic amines, are recognized and controlled, this is not the case for textile dyes in general. In a modified Ames test with fabric tested in situ ("Ames spot test"), 9.2\% of 196 tested textile samples showed mutagenic effects in TA98 and/or TA100 (Knasmüller et al., 1993). Currently, there are several thousand textile dyes from various chemical classes in use in Europe. Most of them belong to the so-called existing substances, which have been placed on the European market before an effective chemical regulation has been installed in 1983. Toxicological data are often scarce for these substances.

In a recent research project, funded within the Fifth Framework Programme of the EU, research institutions collaborated with nine small and medium-sized textile finishing companies (TFCs) from eight European countries to investigate the textile dyes currently in use within these companies.

The aims of the project were

- $\quad$ to check whether sufficient data are available to assess possible genotoxic properties of textile dyes

- $\quad$ to investigate whether genotoxicity is a problem by using data from all sources including own laboratory tests

- $\quad$ to substitute textile dyes identified as having genotoxic properties from the textile finishing process.

This paper describes the type and amount of data used for the assessment, the overall results for the textile dyes scrutinized and problems encountered during the evaluation process.

\section{Methods}

\section{Literature search and data organisation}

Relevant publications were retrieved using $\mathrm{Cl}$ (colour index) names and CAS registry numbers extracted from safety data sheets and/or provided by the dye producing companies (DPCs). Data were retrieved from the literature by searching in databases (Medline, Toxline) as well as via internet to locate other relevant sources. ChemID was used to chemically identify dye stuffs (see figure 1 for the relations between various data sources). In addition to these sources, DPCs were asked for unpublished genotoxicity test results. As dyes can be contained in various products (from one or several DPCs) and test results were available for both ready-to-use products and for individual dye ingredients, this complex matrix of data has been captured and organized in a newly established relational database (MUTATEX, platform Microsoft ACCESS $^{\circledR}$ ). The MUTATEX database allows connecting TFC-specific information (use patterns, consumption) with data on the formulated products (composition, genotoxicity data) and dye ingredients (chemical identification, genotoxicity data). 


\section{Mutagenicity tests}

Dye samples were provided by the participating textile finishing companies as they are used for textile dyeing.

Tests for reverse mutation in S. typhimurium (Ames-Test) (Ames et al., 1973) were carried out following OECD TG 471 (1997) and EU Commission directive 2000/32/EC, B.13/14. In deviation of the guidelines mentioned above only the two $S$. typhimurium strains TA98 and TA100 (Dr. B. N. Ames, Berkley, CA, USA.) were applied in the presence and absence of a metabolic activation system (S9 Moltox, Boone, NC, USA). These strains are commonly used for screening on mutagenicity because they indicate both frame shift (hisD3052 with TA98) and base pair (hisG46 with TA100) mutations. They are recommended in the DIN guideline 38415-4 for the testing of waste water. Experiments with unclear results were repeated in independent studies. A sample was evaluated as mutagenic, if there was more than a doubling of revertant colonies per plate in comparison to the control in at least one strain with or without the metabolic activation system and/or if a concentration-related increase occurred over the range tested. Additionally, the increase of the number of revertant colonies was checked statistically using the Wilcoxon rank sum test according to Mann \& Whitney (Wahrendorf et al., 1985). Testing was started with five concentrations between 0.5 and 5,000 $\mathrm{\mu g} /$ plate. Additional tests were performed with smaller concentration steps.

The Mouse Lymphoma Assay (MLA) was applied to dye stuffs which proved to be Ames positive. Tests using cell line L5178Y $\mathrm{TK}^{+-}$Clone 3.7.2.C (obtained from Schering, Berlin, Germany) were performed in 96-well microtiter plates following OECD TG 476 (1997) and EU Commission directive 2000/32/EC, B.17. In a first test, five concentrations between 15.8 and $5,000 \mu \mathrm{g} / \mathrm{ml}$ were tested. Further tests were performed with smaller concentration steps.

The test was evaluated as valid if the cloning efficiency (CE2) was at least $10 \%$. A sample was evaluated as positive if the mutant frequency was elevated to more than about 100 per $10^{6}$ surviving cells in comparison to the control in at least one concentration and if this increase was significant (one way ANOVA followed by Dunnett's test). The test allows the differentiation of chromosome and gene mutations both by the determination of small and big colonies (Moore \& Doerr 1990).

Table 1: Mutagenicity assessment criteria for textile dye products

\begin{tabular}{|l|l|}
\hline Category & Definition \\
\hline Not mutagenic & Base-level requirements fulfilled, bacterial test and/or MCGT negative \\
\hline $\begin{array}{l}\text { Not mutagenic/ } \\
\text { incomplete }\end{array}$ & $\begin{array}{l}\text { Base-level requirements not fulfilled, available test (usually bacterial } \\
\text { test) negative }\end{array}$ \\
\hline One test positive & $\begin{array}{l}\text { One test positive, without refutation by other tests (e.g. the bacterial } \\
\text { test is the only test available and leads to positive results), includes } \\
\text { also some cases with controversial data }\end{array}$ \\
\hline Mutagenic & $\begin{array}{l}\text { Base-level requirements fulfilled, both tests or MCGT positive (other } \\
\text { data, e.g. in vivo tests for clastogenicity or }{ }^{32} \text { P post labelling, are also } \\
\text { considered, if available) }\end{array}$ \\
\hline Not tested & Mutagenicity data on the dye product or on components are lacking \\
\hline No data & $\begin{array}{l}\text { No data on identity or genotoxicity provided by the producer, other kind } \\
\text { of data also lacking }\end{array}$ \\
\hline
\end{tabular}




\section{Evaluation criteria}

The evaluation of mutagenic properties follows the base-level requirements and the testing strategy of the EU Technical Guidance Document (TGD) (EC, 2003). Base-level testing requires two in vitro assays, a bacterial test (usually reverse mutations in $S$. typhimurium) and a mammalian cell genotoxicity test (MCGT). If available, in vivo results are regarded as superior to in vitro tests. In the TGD, an in vivo test for unscheduled DNA synthesis is recommended in case of a positive result for gene mutations in an MCGT. In contrast, dye producers applied a micronucleus test in vivo in most cases. Due to the fact that suitable in vivo assays for gene mutations are lacking, substances, which showed positive results in in vitro tests for gene mutations (e.g. mutations at the hypoxanthine phosphoribosyltransferase (HPRT) locus) but were negative in vivo for clastogenicity (e.g. in a micronucleus assay) were assessed to be not mutagenic. But substantial uncertainty remains in these cases.

\section{Results}

\section{Data sources and availability}

Two hundred eighty-one different textile dye products (ready-to-use products bought by the textile finishing companies (TFCs) from various dye producers) have been in use at the TFCs at the start of the project. Data on genotoxic effects of the dyes mainly stem from three different sources: published data, data provided by dye producers and results obtained by laboratory tests during the project (figure 1). At the start of the project, all major textile dye producing companies (DPCs) supplying dye products to the TFCs have been contacted. Exchange of data has been agreed with the dye producers. Only one DPC refused to cooperate and did not contribute data to the project.

Figure 1: Flow chart depicting data sources and individual steps of the evaluation process

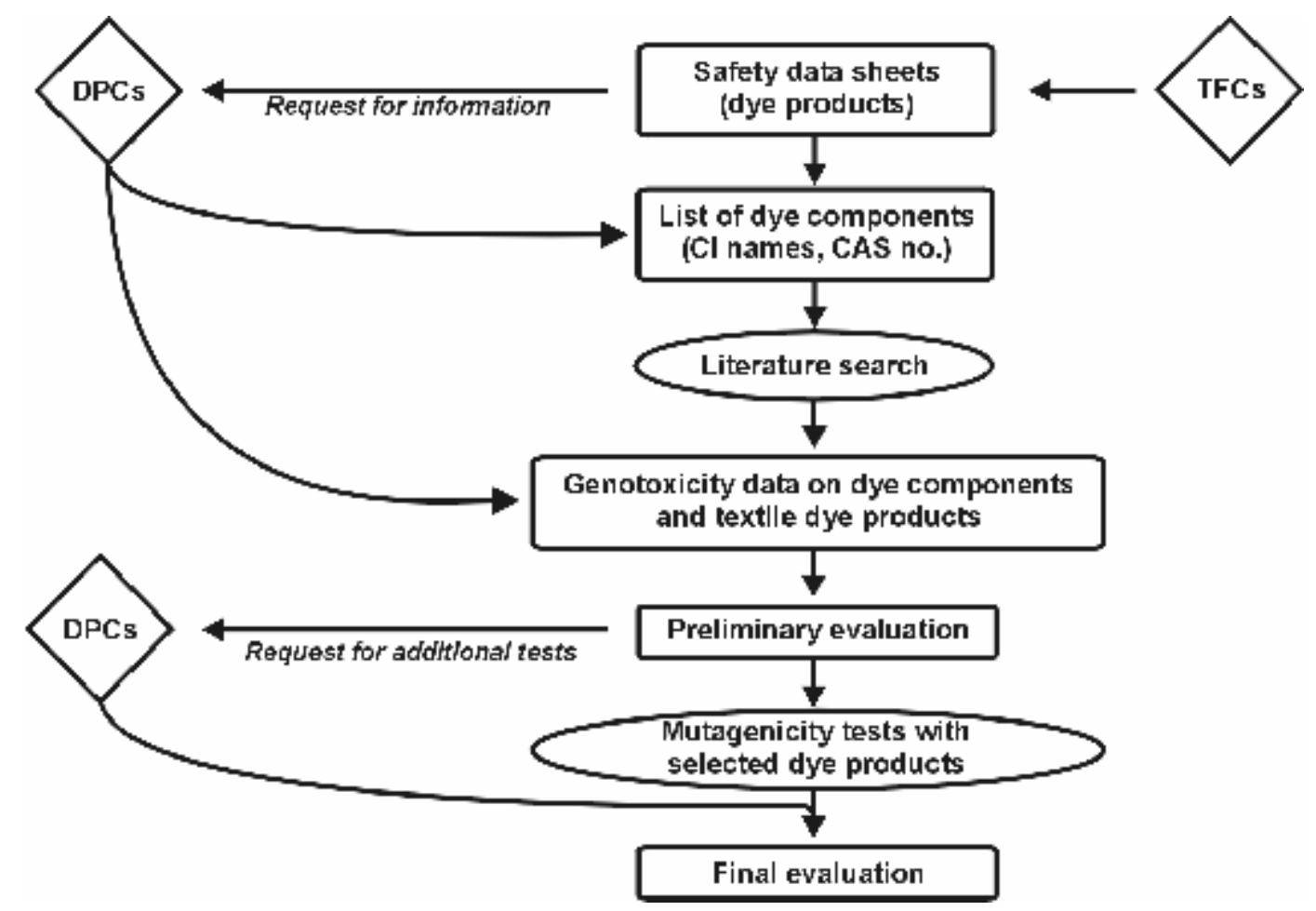


The amount of genotoxicity data available from the DPCs differed substantially between companies. Whereas some dye producers had (some kind of) test results for up to $90 \%$ of their products (or dye components), others had basically none. While unpublished and therefore not peer-reviewed, the test results provided by the DPCs have been carried out according to the latest guidelines and are generally judged to be reliable. Compared to other sources (safety data sheets (SDS), publications) producers' data were the most relevant in terms of quantity (figure 2). Still, no genotoxicity data were available for 98 dye products (35\%) after capturing published data and unpublished test results provided by the producers. For about $22 \%$, at least one test result was available but base-level requirements were not fulfilled.

\section{Assessment of mutagenicity using published data}

Using data from the literature, four textile dye components were judged to be mutagenic according to the assessment criteria described (table 2). These dyes were contained in seven different products from 5 producing companies.

Figure 2: Relative importance of various data sources for the assessment of mutagenicity of textile dye products

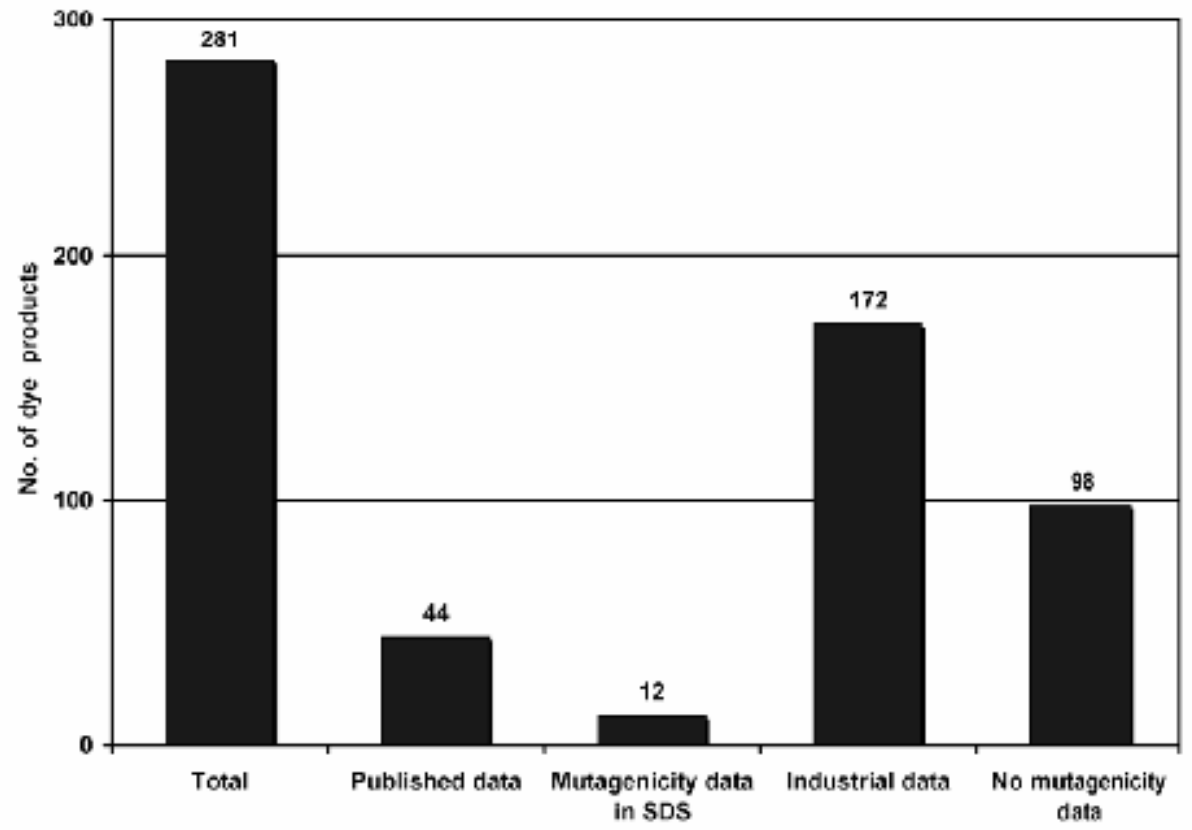


Table 2: Textile dyes assessed to be mutagenic: Genotoxicity data and references

\begin{tabular}{|c|c|c|}
\hline Dye component & CAS No. & Data \\
\hline Acid Green 16 & $12768-78-4$ & $\begin{array}{l}\text { mutagenic in S. typhimurium (TA98, } 1538+\mathrm{S} 9,500-2500 \\
\mu \mathrm{g} / \text { plate (Przybojewska et al., 1989) } \\
\text { negative in S. typhimurium (TA98, TA100+/-S9, } 5000 \mu \mathrm{g} / \text { plate } \\
\text { (Kaur et al., 1993b) } \\
\text { positive response for sister chromatid exchange (SCE) in vitro } \\
\text { (Baranski et al., 1992) } \\
\text { clastogenic effects in micronucleus tests in vivo with BALB/c } \\
\text { mice (75-90 mg/kg, i.p.) (Przybojewska et al., 1989; Wronska- } \\
\text { Nofer et al., } 1997 \text {; Zawadzka et al., 1993) }\end{array}$ \\
\hline $\begin{array}{l}\text { Basic Green } 4 \\
\text { (malachite green) } \\
\text { (see below) }\end{array}$ & $10309-95-2$ & $\begin{array}{l}\text { contradictory results in S. typhimurium and other test systems, } \\
\text { see below } \\
\text { DNA adducts ( }{ }^{32} \mathrm{P} \text { post-labelling) (Culp et al., 1999) }\end{array}$ \\
\hline $\begin{array}{l}\text { Disperse Red } 60 \text { (see } \\
\text { below) }\end{array}$ & $17418-58-5$ & $\begin{array}{l}\text { mutagenic in S. typhimurium (TA98, +S9, 0,1-10 mg/plate) } \\
\text { (NCI, 1989a; NTP, 2003) } \\
\text { negative in S. typhimurium (TA 98, TA 100, TA 1535, TA 1537, } \\
\text { only -S9) (ETAD, 1988) } \\
\text { negative for chromosome aberrations and sister chromatid } \\
\text { exchanges (no further details) (NTP, 2003) } \\
\left.\text { mutagenic in mouse lymphoma assay (L5178Y/TK }{ }^{+/},-S 9\right) \\
\text { (NCI, 1989b) }\end{array}$ \\
\hline $\begin{array}{l}\text { Natural Red } 8, \text { roots } \\
\text { of rubia tinctorum } \\
\text { (plant dye) }\end{array}$ & $84650-16-8$ & $\begin{array}{l}\text { rubia tinctorum extracts and lucidin mutagenic in several } S \text {. } \\
\text { typhimurium strains, lucidin induced mutations at HGPRT } \\
\text { locus, unscheduled DNA synthesis, and DNA adducts (Yasui } \\
\text { and Takeda, 1983; Kawasaki et al., 1992; Poginsky et al., } \\
\text { 1991; Westendorf et al., 1988) } \\
\text { rubia tinctorum extracts induced hepatocellular and tubular } \\
\text { adenoma in rats (Westendorf et al., 1998) }\end{array}$ \\
\hline
\end{tabular}

Malachite green (MG, Basic Green 4), a triphenylmethane dye, is not only used for textile finishing but also as a fungicide in aquaculture and for other purposes. There is a substantial database on genotoxicity; nevertheless, its mutagenic potential is far from clear. MG gave contradictory results in previous Ames tests (Clemmensen et al., 1984; Yamaguchi, 1988; ETAD, 1988; Kaur et al., 1993a), but a recent test carried out according to OECD guideline 471 showed no mutagenicity in TA97a, TA98, TA100, and TA102 with and without metabolic activation (Fessard et al., 1999). Positive results with gene mutation tests with E. coli and yeast have been reported by Combes and Haveland-Smith (1982).

Fessard et al. (1999) also stated a negative result in an assay for mutations at the hypoxanthine-guanine phosphoribosyltransferase (HGPRT) locus in Chinese hamster ovary $(\mathrm{CHO})$ cells. Evaluation was restricted, however, due to severe cytotoxicity. According to the same authors, MG damaged DNA in a Comet assay with $\mathrm{CHO}$ cells. DNA strand breaks after alkaline elution have been reported by Mahudawala et al. (1999). MG inhibited DNA synthesis (Rao et al., 1995; 1998) and induced malignant transformation of mammalian cells in vitro (Panandiker et al., 1993; Mahudawala et al., 1999).

In vivo mutagenicity tests revealed no mutagenic potential (micronucleus test with mice: Clemmensen et al., 1984; mouse spot test: Jensen, 1984). But a recent report by Culp et al. (1999) showed a dose-dependent increase of DNA adducts in the liver of mice and rats after 28 days of feeding MG in concentrations up to $600 \mathrm{ppm}$. MG promoted pre-neoplastic lesions of the liver after induction with N-nitrosodiethylamine (Fernandes et al., 1991; Gupta et al., 2003). 
MG is currently under test for carcinogenicity within the US National Toxicology Program, and these studies will allow to better judge the relevance of the reported data. Up to that point, there remains concern with regard to a possible mutagenic potential of MG.

Another dye listed in table 2 is an extract of plant roots (rubia tinctorum, madder roots, $\mathrm{Cl}$ natural red 8). The major genotoxic constituent is regarded to be lucidin, a hydroxyanthraquinone constituent. Further investigations on mutagenic effects of madder root extracts and on the presence of lucidin at various stages of the dyeing process with Rubia tinctorum were performed and reported by Jäger et al. (2003a).

\section{$\underline{\text { Overall mutagenicity assessment }}$}

After prioritizing according to consumption and technical importance for the TFCs, untested dye products were selected for testing. Fifteen out of $53(28 \%)$ dye products tested proved to be positive in $S$. typhimurium, strains TA98 and/or TA100. Nine of these positive samples were further tested in the MLA and $6(67 \%)$ gave positive results in this mammalian cell test (see Jäger et al., 2003b for more details).

From these investigations, together with published and industrial data, the following picture emerges for the 281 textile dye products assessed (figure 3 ):

- $\quad$ for 107 dye products (or dye components) base-level requirements are fulfilled and give no hint to mutagenic activity

- $\quad$ for 73 products only one test is available with no indication of a mutagenic potential

- $\quad$ for 16 products there is a positive test result in the only test existing or results from several tests led to contradictory results leaving suspicion of mutagenic activity

- 14 dye products are assessed to have mutagenic activity

- $\quad$ still, after substantial laboratory testing within this project, there are 71 dye products currently in use in the TFCs involved with genotoxicity data unknown or completely lacking. 
Figure 3: Overall mutagenicity assessment for 281 textile dye products, based on published data, test results provided by dye producing companies and own laboratory test results (for categories see table 1)

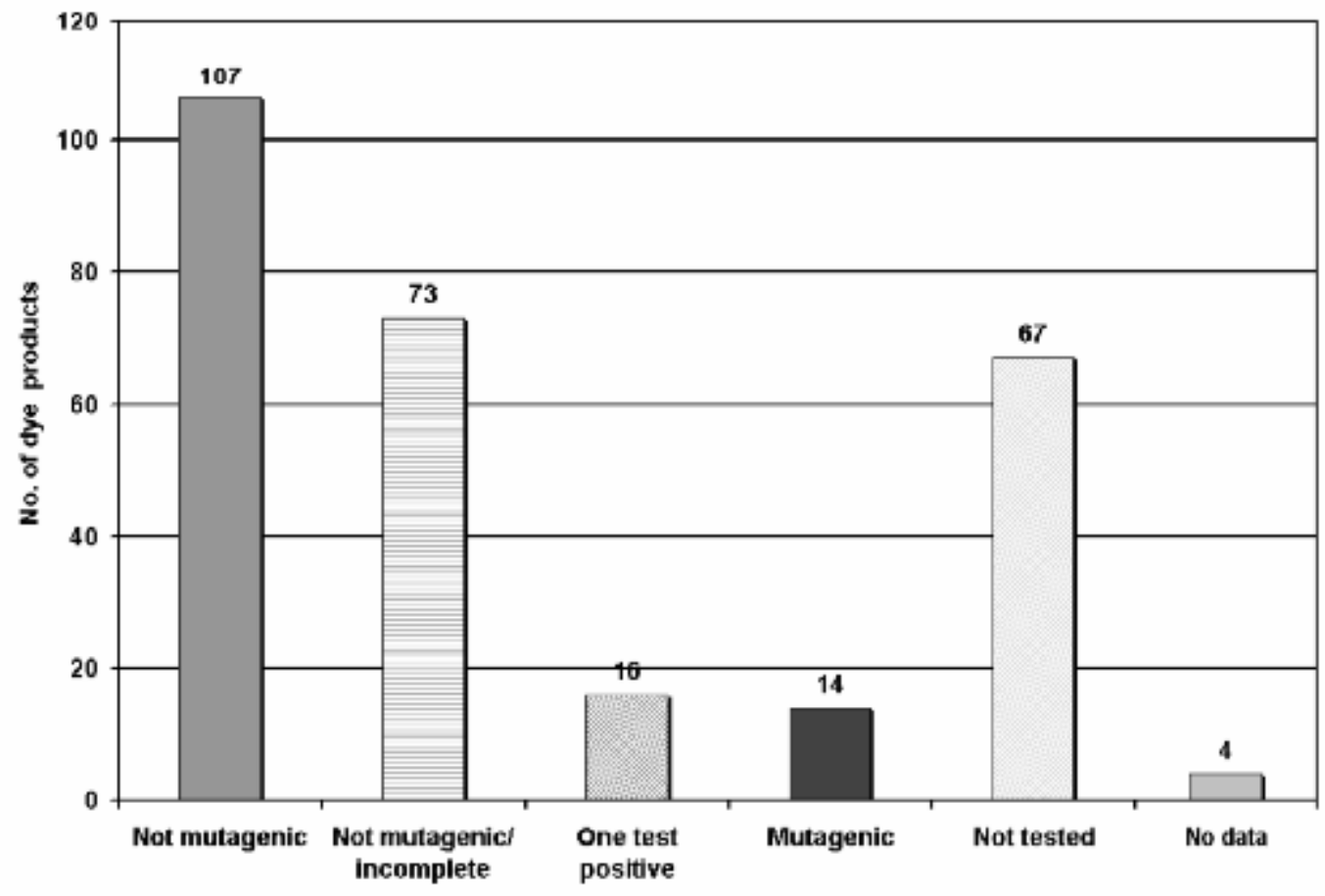

\section{$\underline{\text { Importance of impurities }}$}

With several of the tested products discrepancies could be observed between the results obtained in S. typhimurium with the formulated product and the results reported by producers with the pure dye (technical grade). Whereas in general the formulated products used by the TFCs were tested, in the case of one dye product, Turquoise Cibacrone PGR (chemical nature and name of the dye contained unknown), a direct comparison between the technical pure $^{1}$ and the formulated dye has been made in S. typhimurium.

The formulated product showed a weak but significant mutagenic response in TA 98 with metabolic activation at the highest concentration tested (5000 $\mu \mathrm{g} / \mathrm{plate})$. In contrast, the technical grade pure dye was inactive in S. typhimurium (figure 4), which is in agreement with the producer's data. Upon further testing, the dye product also showed mutagenic effects in the mouse lymphoma assay with metabolic activation. It induced a statistically significant increase of small colonies, which is indicative for chromosomal mutations. At 2500 $\mu \mathrm{g} / \mathrm{ml}$ and higher, mutation frequency was more than threefold compared to controls (figure $5)$.

\footnotetext{
${ }^{1}$ kindly provided by Ciba AG, Basle, Switzerland
} 
Figure 4: Response of a textile dye product, Turquoise Cibacrone PGR, and its dye constituent (technical grade) in S. typhimurium (TA98) with and without metabolic activation

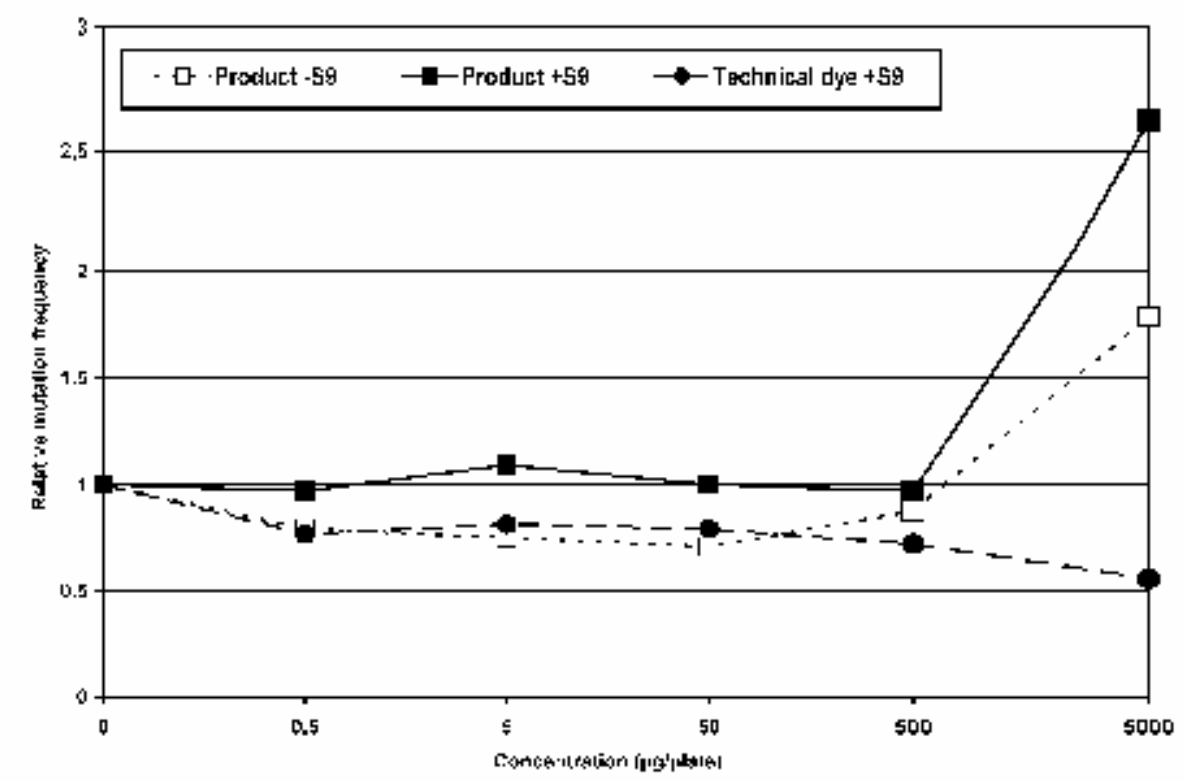

The different results in the Ames test with the technical grade dye and the formulated product might be due to mutagenic ingredients of the product others than the dye. Chemical interactions between constituents of the product leading to mutagenic reaction products are possible in principle, but not likely.

\section{Contradictory data}

In some cases available data were contradictory, leading to extensive discussions. This is exemplified with recent results on Lanaset and other dyes. Wollin and Görlitz (2002; 2003) published results on several textile dyes applying a bacterial assay (reverse mutation in S. typhimurium), the Single Cell Gel (SCG)/Comet assay, and the in vitro micronucleus assay and in part obtained results which deviated from industrial data (table 3). With the micronucleus assay, they used a non-validated test design with an immortalized human keratinocytes cell line (HaCaT) and for some of the dyes additionally natural human keratinocytes. All of the dyes tested gave positive results in this micronucleus assay in vitro and in the Comet assay. MCGT carried out with these substances on behalf of the dye manufacturers according to OECD guidelines or corresponding drafts (e.g. test for gene mutations (HPRT-locus in L5178Y cells) and test for chromosomal aberrations in Chinese hamster ovary cells) showed no mutagenic response. Lanaset Yellow 2R was subjected by the DPCs to a micronucleus test in vitro in L5178Y cells and gave a negative result. Reasons for these discrepancies might include an unusual susceptibility of the test using keratinocytes or difficulties in demonstrating mutagenic effects due to 
overlapping cytotoxicity, for which there are some hints from testing the ingredients of Lanaset Yellow 2R. To clarify these discrepancies additional investigations should be carried out. With another dye containing Acid Black 220, the micronucleus test in vitro (L5178Y) gave a positive result (in agreement with the results obtained with keratinocytes) but a subsequent micronucleus test in vivo was negative.

Figure 5: Response of the textile dye Turquoise Cibacrone PGR in the Mouse Lymphoma Assay with metabolic activation (positive control: benzo[a]pyrene $(4 \mu \mathrm{g} / \mathrm{ml})$, total MF >1000)

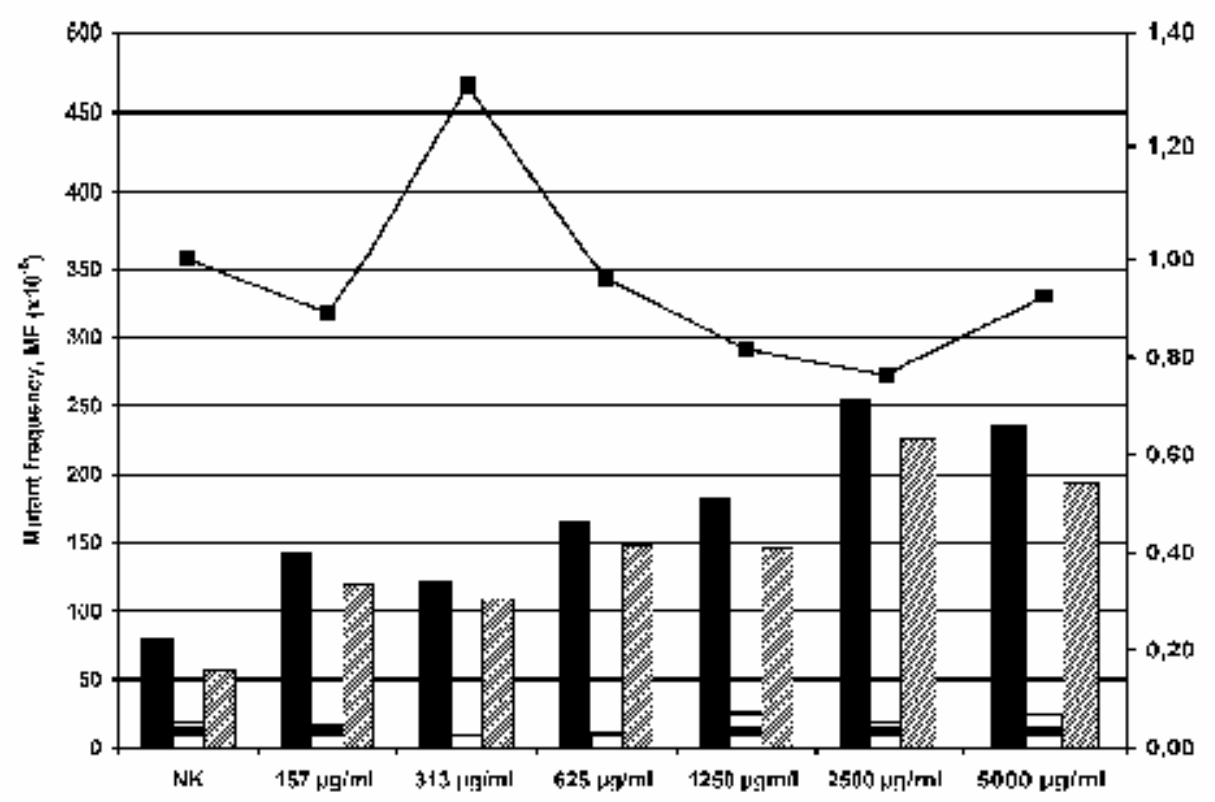


Table 3: Contradictory data from literature and from industry for 4 textile dye products

\begin{tabular}{|c|c|c|c|}
\hline $\begin{array}{l}\text { Textile dye } \\
\text { product }\end{array}$ & Producer & Producer's data (unpublished) & Wollin and Görlitz (2002; 2003) \\
\hline $\begin{array}{l}\text { Isolan Grey } \\
\text { S-GL }\end{array}$ & DyStar & $\begin{array}{l}\text { product } \\
\text { positive in micronucleus test in vitro (mouse lymphoma cells, } \\
\text { L5178Y) without metabolic activation, accompanied by cytotoxicity } \\
\text { negative in micronucleus test in male and female Sprague Dawley } \\
\text { rats in vivo }(2 \times 2000 \mathrm{mg} / \mathrm{kg})\end{array}$ & $\begin{array}{l}\text { product: } \\
\text { positive in S. typhimurium, TA98 +/-S9 (Ames test) } \\
\text { positive in micronucleus test in vitro (mitotic shake } \\
\text { off procedure) with a immortalized human } \\
\text { keratinocyte (HaCaT) cell line (without metabolic } \\
\text { activation) }\end{array}$ \\
\hline $\begin{array}{l}\text { Lanaset Navy } \\
\text { (Marine) R }\end{array}$ & $\begin{array}{l}\text { Ciba } \\
\text { Specialty } \\
\text { Chemicals }\end{array}$ & $\begin{array}{l}\text { dye component: } \\
\text { positive in S. typhimurium, strains TA98, TA100, TA1535, TA1537 } \\
\text { +S9 (Ames test) } \\
\text { negative for gene mutations (HPRT, L5178Y cells) +/-S9 } \\
\text { negative in CA test (chromosomal aberrations) in V79 cells +/-S9 }\end{array}$ & $\begin{array}{l}\text { product: } \\
\text { positive in S. typhimurium, TA98 +/-S9 (Ames test) } \\
\text { positive in micronucleus test in vitro (mitotic shake } \\
\text { off procedure) with HaCaT cell line and normal } \\
\text { human epidermal keratinocytes (without metabolic } \\
\text { activation) }\end{array}$ \\
\hline $\begin{array}{l}\text { Lanaset Red } \\
\text { G }\end{array}$ & $\begin{array}{l}\text { Ciba } \\
\text { Specialty } \\
\text { Chemicals }\end{array}$ & $\begin{array}{l}\text { dye component: } \\
\text { positive in S. typhimurium, strains TA98, TA100, TA1535, TA1537 } \\
\text { +S9 (Ames test) } \\
\text { negative for gene mutations (HPRT, L5178Y cells) +/-S9 } \\
\text { negative in test for chromosomal aberrations (V79 cells) +/-S9 }\end{array}$ & $\begin{array}{l}\text { product: } \\
\text { positive in S. typhimurium, TA98 +/-S9 (Ames test) } \\
\text { positive in micronucleus test in vitro (mitotic shake } \\
\text { off procedure) with HaCaT cell line and normal } \\
\text { human epidermal keratinocytes (without metabolic } \\
\text { activation) }\end{array}$ \\
\hline $\begin{array}{l}\text { Lanaset } \\
\text { Yellow 2R }\end{array}$ & $\begin{array}{l}\text { Ciba } \\
\text { Specialty } \\
\text { Chemicals }\end{array}$ & $\begin{array}{l}\text { product: } \\
\text { negative in S. typhimurium, strains TA98, TA100, TA1535, TA1537 } \\
\text { +/-S9 (Ames test) } \\
\text { negative in micronucleus test in vitro (L5178Y cells, +/- metabolic } \\
\text { activation) } \\
\text { dye component 1: slight clastogenic effect in micronucleus test in vitro } \\
\text { with metabolic activation in presence of intensive cytotoxicity } \\
\text { dye component 2: slight clastogenic effect in micronucleus test in vitro } \\
\text { without metabolic activation in presence of intensive cytotoxicity } \\
\text { clastogenicity was judged by investigators to be irrelevant due to } \\
\text { cytotoxicity }\end{array}$ & $\begin{array}{l}\text { product: } \\
\text { negative in S. typhimurium, TA98, TA100, +/-S9 } \\
\text { (Ames test) } \\
\text { positive in micronucleus test in vitro (mitotic shake } \\
\text { off procedure) with HaCaT cell line (without } \\
\text { metabolic activation) }\end{array}$ \\
\hline
\end{tabular}




\section{Discussion}

This examination of available data on genotoxicity of textile dyes revealed substantial data gaps for a lot of these substances. Unpublished test results of the dye manufacturers emerged as an important data source, but substantial differences between DPCs became obvious: Voluntary testing of products or ingredients is common with some but not with other companies. Due to a well established cooperation between the TFCs, the DPCs, and the research institutions assessing the dyes within this EU research project, these data were made available for an overall assessment. Outside this research framework data are provided by DPCs only upon request to their customers. But textile finishing companies do not have the expertise to ask for these data, let alone to make proper use of it. Therefore, a data exchange and evaluation process leading to increased use of thoroughly tested and non-mutagenic textile dyes can only be envisioned if awareness within the textile production chain is increased. The situation might change after implementation of the new European Union chemicals regulation, which will not differentiate any more between new and existing substances (EU White Paper on the Strategy for a future Chemicals Policy; EC, 2001).

The evaluation performed indicates that dyes with potential mutagenic effects are in use in the textile finishing industry. Fourteen out of the 281 dye products included proved to have mutagenic potential according to the assessment criteria applied. Of the dye products tested in the S. typhimurium test within the project, $28 \%$ gave positive results in TA98 and/or TA100, and about $67 \%$ of the Ames-positive dyes tested in the MLA proved to be mutagenic in this mammalian cell assay. Using these numbers to predict the chance to find mutagenic samples within the 71 dye products without test results and within the 14 dyes suspicious to be mutagenic due to positive results from the first test about 15 to 20 additional potentially genotoxic substances can be expected. This sums up to more than $10 \%$ of the textile dyes showing mutagenic activity. Whereas these numbers are only insufficient attempts to quantify the unknown, it gives an idea of the dimension of the problem.

In agreement with Knasmüller et al. (1993) it can be concluded from our results that mutagenic effects of poorly investigated textile dyes pose a problem. These authors investigated textile samples in situ in the Ames test and found more than $9 \%$ of the samples showing positive results. Discussion of genotoxic substances on textiles in recent years focused on azo dyes splitting off carcinogenic amines. And indeed, recent investigations state that these dyes can still be found on fabric (Yassini et al., 1997; Danish EPA, 1998; Zeilmaker et al., 1999). The participating TFCs banned these hazardous azo dyes already years ago from their production process. But these azo dyes may be a problem especially with textile products imported to Europe (Lokhande and Naik, 1996). Since none of the dye stuffs considered here belongs to this group it must be stated that there are other textile dyes which may give rise to mutagenic effects.

As the project was concerned with both occupational safety during the textile finishing process and with consumer protection, leachability of hazardous dyes from clothes was not addressed in the first place. It can be expected that at least for some chemical classes as, e.g. reactive dyes, exposure of consumers is low. But as shown e.g. by Knasmüller et al. (1993) with the Ames spot test, a relevant proportion of dyes (9.2\%), which are active in $S$. typhimurium, is leachable from textile samples. This was confirmed by own results with the Ames spot test using 92 textile and yarn samples from the TFCs. About $5.4 \%$ of all samples tested were positive in this rather insensitive test with TA98 (Jäger et al., 2003c). 
As far as the chemical nature of the dyes was revealed, no chemical class of dyes was particularly represented in the group of potentially hazardous dyes. So, membership in chemical classes and structure-activity relationships are of limited value to pre-select potential mutagenic dyes.

Using the communication established during the project, the TFCs involved are working to eliminate the mutagenic dyes identified from their production process. Problems encountered vary with the type of dye, with differing substrates and with the price of alternative products (Jäger et al., 2003c). Preliminary results from this substitution process show that textile dyeing avoiding these dyes is feasible.

\section{Acknowledgements}

The project was funded by the European Commission under contract number EU CRAFT QLK4-CT2000-70158. We would like to thank the dye producing companies and especially Dr. Anette Weber, DyStar (Leverkusen, Germany) and Dr. Bruno Büttler, Ciba Speciality Chemicals (Basle, Switzerland) for supporting the project by providing data.

\section{References}

Ames BN, Frank DL, William ED 1973. An improved bacterial test system for the detection and classification of mutagens and carcinogens. Proc. Nat. Acad. Sci. USA 70: 782-786

Baranski B, Przybojewska B, Spiechowicz E, Wyszynska K, Zimnicki J. 1992. Identification of potential carcinogenic dyes and intermediates on the basis of their genotoxicity. Med Pr 43: 469-477.

Clemmensen S, Jensen JC, Jensen NJ, Meyer O, Olsen P, Würtzen G. 1984. Toxicological studies on malachite green: a triphenylmethane dye. Arch Toxicol 56: 43-45.

Combes RD, Haveland-Smith RB. 1982. A review of the genotoxicity of food drug and cosmetic colors and other azotri phenyl methane and xanthene dyes. Mutat Res 98: 101-248.

Culp SJ, Blankenship LR, Kusewitt DF, Doerge DR, Mulligan LT, Beland FA. 1999. Toxicity and metabolism of malachite green and leucomalachite green during short-term feeding to Fischer 344 rats and B6C3F1 mice. Chem Biol Interact 122: 153-170.

Danish EPA, Danish Environmental Protection Agency, 1998. Azocolorants in Textiles and Toys, Environmental Health Assessment. Environmental Project no. 416 1998. Danish Environmental Protection Agency: Copenhagen. http://www.mst.dk/homepage/ [May 2003]

EC, European Commission, 2001. White Paper: Strategy for a future chemicals policy. COM(2001) 88 - C5-0258/2001 - 2001/2118(COS)), European Commission: Brussels (online: http://europa.eu.int/comm/environment/chemicals/whitepaper.htm, accessed May 2003)

EC, European Commission, 2003. Technical guidance document on risk assessment. European Chemicals Bureau, Office for Official Publications of the European Communities: Luxemburg. http://ecb.jrc.it/Technical-Guidance-Document/ [May 2003]

ETAD, Ecological and Toxicological Association of Dyes and Organic Pigments Manufacturers, 1988, Toxicological Testing of Major Colorants. Executive Summary on the ETAD Project T 2015, Basel, Switzerland, 1988

Fernandes C, Lalitha VS. 1991. Enhancing effect of malachite green on the development of hepatic pre-neoplastic lesions induced by N-nitrosodiethylamine in rats. Carcinogenesis 12: 839-845. 
Fessard V, Godard T, Huet S, Mourot A, Poul JM. 1999. Mutagenicity of malachite green and leucomalachite green in in vitro tests. J Appl Toxicol 19: 421-430.

Gupta S, Sundarrajan M, Rao KV. 2003. Tumor promotion by metanil yellow and malachite green during rat hepatocarcinogenesis is associated with dysregulated expression of cell cycle regulatory proteins. Teratog Carcinog Mutagen 23, Suppl. 1: 301-312.

Jäger I, Hafner C, Welsch C, Schneider K, Bollhalder X, Hofer W, Westendorf J, 2003a. Mutagenicity in the Ames test of madder root in dyeing processes of the textile industry. Submitted to Toxicology

Jäger I, Hafner C, Schneider K. 2003b. Mutagenicity of different textile dye products in Salmonella thyphimurium and mouse lymphoma cells. Mutation Research 2004 (in print).

Jäger I, Schneider K, Janak P, Fues D. 2003c. European textile industry successfully completed a European CRAFT project and made production safer for consumers, workers and the environment. In preparation for submission to Melliand Textilberichte

Jensen NJ. 1984. Lack of mutagenic activity of malachite green in the mammalian spot test. Mutat Res 130: 248.

Kaur A, Sandhu RS, Grover IS. 1993a. Screening of azo dyes for mutagenicity with Ames/Salmonella assay. Environ Mol Mutagen 22: 188-190.

Kaur A, Singh R, Grover IS. 1993b. Mutagenicity testing of textile (azo) dyes with Salmonella/microsome assay. J Environ Biol 14: 327-333.

Kawasaki Y, Goda Y, Yoshihira K. 1992. The mutagenic constituents of Rubia tinctorum. Chem Pharm Bull 40: 1504-1509.

Knasmüller S, Zöhrer E, Kainzbauer E, Kienzl H, Colbert B, Lamprecht G, Schulte-Hermann R. 1993. Detection of mutagenic activity in textiles with Salmonella typhimurium. Mutat Res 299: 45-53.

Lokhande HT, Naik SR. 1996. Role of eco-standards in textile exports. Colourage : 19-30.

Mahudawala DM, Redkar AA, Wagh A, Gladstone B, Rao KVK. 1999. Malignant transformation of Syrian hamster embryo (SHE) cells in culture by malachite green: an agent of environmental importance. Indian J Exp Bio/ 37: 904-918.

Moore MM, Doerr,CL. 1990. Comparison of chromosome aberration frequency and small-colony TK deficient mutant frequency in $\mathrm{L} 5178 \mathrm{Y} / \mathrm{TK}^{(+-)}-3.7 .2 \mathrm{C}$ mouse lymphoma cells. Mutagenesis 5: 609614.

$\mathrm{NCl}$, National Cancer Insitute, 1989a. Final Report: Salmonella/mammalian-microsome plate incorporation mutagenicity assay (Ames test), Test Article 31840 (CI Disperse Red 60, 17418-585), R. H. C. San, K. A. Springfield, Microbiological Associates, Inc., Rockville, MD, USA, Laboratory Study No. C146.501017, submitted to the National Cancer Institute, Division of Cancer Etiology, Rockville, Maryland, USA, unpublished

$\mathrm{NCl}$, National Cancer Insitute, 1989b. Mouse Lymphoma Assay (L5178Y TK +/-). Test Article Code \# 31840 (Cl Disperse Red 60, 17418-58-5) (ML-NCI \#251), Contract No.: NO1-CP-41004, J.W. Harbell, Microbiological Associates, Inc., Rockville, MD, USA, submitted to the National Cancer Institute, Carcinogenesis Contract Section, Silver Spring, Maryland, USA, unpublished

NTP, National Toxicology Program. 2003. Testing status: C.I. Disperse Red 60. http://ntpserver.niehs.nih.gov/htdocs/Results Status/Resstatc/M88155.Html [May 2003]

Panandiker A, Fernandes C, Rao TK, Rao KV. 1993. Morphological transformation of Syrian hamster embryo cells in primary culture by malachite green correlates well with the evidence for formation of reactive free radicals. Cancer Lett 74: 31-36. 
Platzek T. 1996. Wie groß ist die gesundheitliche Gefährdung durch Textilien wirklich?. Melliand Textilberichte, Sonderdruck : 4S.

Poginsky B, Westendorf J, Blömeke B, Marquardt H, Hewer A, Grover PL, Phillips DH. 1991. Evaluation of DNA-binding activity of hydroxyanthraquinones occurring in Rubia tinctorum L.. Carcinogenesis 12: 1265-1271.

Przybojewska B, Baranski B, Spiechowicz E, Szymczak W. 1989. Mutagenic and genotoxic activity of chosen dyes and surface active compounds used in the textile industry. Pol J Occup Med 2: 171185.

Rao KVK. 1995. Inhibition of DNA synthesis in primary rat hepatocyte cultures by malachite green: a new liver tumor promoter. Toxicol Lett 81: 107-113.

Rao KV, Mahudawala DM, Redkar AA. 1998. Malignant transformation of Syrian hamster embryo (SHE) cells in primary culture by malachite green: transformation is associated with abrogation of G2/M checkpoint control. Cell Biol Int 22: 581-589.

Wahrendorf J, Mahon GAT, Schumacher M. 1985. A nonparametric approach to the statistical analysis of mutagenicity data. Mutat Res 147: 5-13.

Westendorf, J, Poginsky, B, Marquardt, H, Groth, G, Marquardt, H. 1988. The genotoxicity of lucidin, a natural component of Rubia tinctorum L., and lucidinethylether, a component of ethanolic Rubia extracts. Cell Biol Toxicol 4: 225-239

Westendorf J, Pfau W, Schulte A. 1998. Carcinogenicity and DNA adduct formation observed in ACl rats after long-term treatment with madder root, Rubia tinctorum L.. Carcinogenesis 19: 2163-2168.

Wollin K-M, Görlitz B-D. 2002. Genotoxicity of textile dyestuffs in the Salmonella microsome assay, the in vitro micronucleus test and single cell gel/comet assay. Naunyn-Schmiedeberg's Arch Pharmacol 365 Suppl.: R561.

Wollin K-M, Görlitz B-D. 2003. Genotoxicity of textile dyestuffs in normal human epidermal keratinocytes and a three-dimensional reconstituted human epidermis model. NaunynSchmiedeberg's Arch Pharmacol 367 Suppl.: R147.

Wronska-Nofer T, Wisniewska-Knypl J, Wyszynska K, Dziubaltowska E. 1997. Genotoxicity of industrial dyes under the inductive effect of ethanol on monooxygenase system in mice. Mutat Res 392: 229-235.

Yamaguchi T. 1988. Adsorption of carcinogenic and/or mutagenic pigments on DNA-binding sepharose. Agric Biol Chem 52: 845-847.

Yassini S, Popp W, Müller G, Norpoth K. 1997. Aromatische Amine in Textilien - Ein kanzerogenes Risiko für den Menschen? In Psychomentale Belastungen und Beanspruchungen im Wandel von Arbeitswelt und Umwelt. Kanzerogenese und Synkanzerogenese. 37. Jahrestagung der Deutschen Gesellschaft für Arbeitsmedizin und Umweltmedizin e.V. in Wiesbaden vom 12. bis 15. Mai 1997, Borsch-Galetke E., Struwe F (eds.). Druckerei Rindt: Fulda; 441-443.

Yasui Y, Takeda N. 1983. Identification of a mutagenic substance, in Rubia tinctorum L. (madder) root, as lucidin. Mutat Res 121: 185-190.

Zawadzka M, Baranski B, Wisniewska-Knypl J, Wronska-Nofer T. 1993. Genotoxic effects of triarylmethane dye acid green 16 after chronic ethanol consumption in mice. Polish J Occup Med Environ Health 6: 391-397.

Zeilmaker MJ, van Kranen HJ, van Veen MP, Janus JA. 2000. Cancer Risk Assessment of Azo Dyes and Aromatic Amines from Tattoo Bands, Folders of Paper, Toys, Bed Clothes, Watch Straps and Ink. RIVM, Rijksinstituut voor Volksgezondheid en Milieu: Bilthoven, RIVM Report 601503019. 